\title{
CROSSHIJABER ANTARA TREND DAN GEJOLAK SOSIAL (ANALISIS PERILAKU CROSSHIJABER PERSPEKTIF AL-QUR'AN DAN PSIKOLOGI)
}

\author{
Hamdan Hidayat \\ Universitas Islam Negeri Sunan Kalijaga, Yogyakarta, Indonesia \\ bamdanbidayat93@gmail.com
}

\begin{abstract}
This article will analyze a behavior brought about by the crosshijaber community in the online media of the Qur'anic perspective and psychology towards social life. Understanding crosshijaber is a community of men who like to use the bijab complete with accessories, psychologically the behavior appears due to several factors, including internal factors such as weak personality, parental education and lack of warmth in the family, while external factors, namely daily intercourse in the environment, the influence of online media and television, so that the condition of a child will lose his identity. This study used descriptive qualitative method. The result is known that crosshijaber behavior is a deviation from norms and values in religion and society. This crosshijaber community is abusing hijab to carry out actions that are troubling the community, such as entering a special place for women, even criminal acts, such as theft. The impact of the crosshijaber behavior gives a negative impression and judgment on women who wear the hijab.
\end{abstract}

Keywords: Al-Qur'an, Crosshijaber, Trend; Online media; Psychology

\begin{abstract}
ABSTRAK
Artikel ini akan menganalisa sebuah perilaku yang ditimbulkan oleh komunitas crosshijaber di media on-line perspektif al-Qur'an dan psikologi terhadap kehidupan bermasyarakat. Pengertian crosshijaber yaitu sebuah komunitas laki-laki yang gemar menggunakan hijab lengkap dengan aksesorisnya, secara psikologi perilaku tersebut muncul diakibatkan oleh beberapa faktor, antara lain faktor internal yaitu lemahnya kepribadian, didikan orangtua dan kurangnya kehangatan dalam keluarga, sedangkan faktor eksternalnya yaitu pergaulan sehari-hari dalam lingkungan, pengaruh media on-line, dan televisi, sehingga kondisi seorang anak akan kehilangan jati dirinya. Penelitian ini menggunakan metode deskriptif kualitatif. Hasilnya diketahui bahwasanya perilaku crosshijaber terdapat sebuah penyimpangan dari norma dan nilai dalam agama dan masyarakat. Komunitas crosshijaber ini menyalahgunakan hijab untuk melakukan tindakan yang meresahkan masyarakat, seperti masuk tempat khusus perempuan, bahkan tindakan kriminal, seperti pencurian. Dampak dari perilaku crosshijaber tersebut memberikan kesan dan penilaian negatif terhadap perempuan yang mengenakan hijab.
\end{abstract}

Kata kunci : Al-Qur'an, Crosshijaber, Trend, Media Online, Psikologi 


\section{PENDAHULUAN}

Pada awalnya pemakaian hijab berfungsi untuk menutup aurat. Tujuannya untuk menghindari lawan jenis melihat lekuk tubuh perempuan, sehingga kehormatan perempuan terjaga. Taimiyah (1994) menyebutkan kehormatan seorang perempuan bisa dilihat bagaimana dirinya menutup bagian-bagian yang tidak seharusnya dilihat oleh lawan jenisnya, begitu juga sebaliknya. Dalam persoalan ini ada dua pendapat mengenai batasan aurat. Pertama, seluruh tubuh perempuan adalah aurat. Kedua, berpendapat bahwa aurat perempuan kecuali bagian wajah dan telapak tangan (Shihab, 2012). Kedua batasan aurat perempuan ini terdapat beberapa toleransi waktu dan tempat, seperti, menjenguk orang sakit, pergi ke masjid untuk melaksanakan sholat, dan untuk menuntut ilmu.(Al-Maududi, t.t.). Dalam hal ini bukan bermaksud untuk mempersempit gerak perempuan, akan tetapi bertujuan supaya terhindar dari zina dan fitnah. (Al-Maududi, t.t.)

Fungsi hijab selain dari menutup aurat, ia juga berfungsi memberi nilai "kereligiusan" bagi seorang perempuan sebagai predikat perempuan muslimah atau perempuan shalihah. Tentu saja pendapat ini menimbulkan pertanyaan bagaimana seorang perempuan yang tidak memakai hijab? Atau seorang perempuan yang sudah melepas hijabnya dalam artian yang semula mengenakan hijab dan dikemudian hari memutuskan untuk menanggalkan hijabnya, apakah dia masih termasuk perempuan muslimah, perempuan shalihah atau tidak?. Pertanyaan-pertanyaan demikian akan terjawab bukan dengan cara melihat dari bagaimana perempuan memakai hijab, akan tetapi dilihat dari bagaimana perempuan bersikap, bertingkah laku dan berekspresi terhadap dirinya dan orang lain. Jadi, sebuah hijab bukanlah patokan dasar apakah seorang perempuan itu muslimah, shalihah atau tidak, akan tetapi setidaknya ketika mengenakan hijab maka akan sedikit berkurang pandangan laki-laki terhadapnya (Budianti, 2011).

Dalam perkembangannya, hijab tidak saja sebagai pakaian yang menutup aurat. Ia telah berinovasi menjadi gaya hidup, fashion dan model pakaian perempuan. Berbagai info terkait hijab dapat dengan mudah diakses di media khususnya media sosial. Begitu pesatnya inovasi tersebut hingga memunculkan varian rosshijaber. Varian ini viral di jagat dunia maya pada tahun 2019 melalui akun media Online, seperti Instagram, Twitter dan Youtube. Pada umumnya seorang yang memakai hijab adalah seorang perempuan, namun berbeda dengan crosshijaber, yang mengenakan hijab adalah laki-laki. Kemunculannya banyak mendapat respon dari netizen. Dibalik adanya penggunaan hijab oleh kaum laki-laki terungkap sebuah jawaban yaitu hijab disalahgunakan oleh oknum-oknum yang tidak bertanggungjawab, seperti masuk crosshijaber kedalam toilet perempuan, berpelukan dengan perempuan, dan masuk ke dalam ruangan khusus perempuan 
lainnya.(https://jabar.tribunnews.com/2019/10/14/heboh-fenomena-crosshijaber-pria-tapipakai-cadar-gamis-dan-masuk-toilet-perempuan, 2019)

Menurut perspektif agama Islam, jelas perilaku crosshijaber adalah sebuah perilaku yang keluar dari syari'at. Menurut fitrahnya, sebuah jenis kelamin akan mengenakan pakaian sesuai dengan jenis kelaminnya masing-masing, dan tidak diperkenankan untuk mengenakan pakaian dari lawan jenisnya, bahkan untuk menyerupai dengan pakaian lawan jenisnya saja sudah termasuk perbuatan yang menyeleweng dalam syari'at agama. Seperti dalam hadis Nabi Muhammad "Dari Ibnu Abbas Radhiya Allahu 'anhuma, dia berkata : "Rasulullah melaknat laki-laki yang menyerupai wanita, dan wanita yang menyerupai laki-laki”. (HR. Bukhari, t.t.)

Sejauh ini studi tentang hijab cenderung melihat tiga perkara. Pertama, studi tentang hijab sebagai sebuah gaya hidup (life style) baru bagi kaum hawa yang seiring dengan berkembang pesatnya zaman. (Budiati, 2011). Kedua, batas ukuran keshalihahan seorang perempuan bisa diukur melalui penggunaan hijab dan hal inilah yang menjadi sebuah fenomena sosial (Yulikhah, 2017). Ketiga, sebuah studi yang berkaitan dengan hijab yang dinamis pada masa kontemporer. (Najitama, 2014)._. Dari ketiga kecenderungan tersebut sangat terlihat sekali bahwasanya sebuah studi tentang hijab hanya dalam lingkup perkembangan yang berada pada kaum hawa, berbeda dengan penelitian ini, yang mana sebuah hijab dikenakan oleh kaum laki-laki dengan adanya maksud tertentu.

Tujuan tulisan ini melengkapi kekurangan dari studi yang ada, yang cenderung melihat posisi hijab dari sudut pandang fashion, life style dan trend yang dinamis, sedangkan pada sudut pandang yang lain terdapat sebuah nilai yang berada dibalik penggunaan hijab bagi komunitasnya. Tulisan ini akan menganalisa tema perilaku crosshijaber dengan fokus pada al-Qur'an dan psikologi. Pertanyaan yang diajukan adalah bagaimana kemunculan crosshijaber melalui media online? Pertanyaan ini akan dijawab dengan terlebih dahulu menjawab; 1). Bagaimana crosshijaber secara psikologis?. 2). Bagaimana konteks hijab dalam pandangan al-Qur'an?; 3). seperti apa perilaku yang ditimbulkan oleh crosshijaber?.

\section{METODE}

Tulisan ini menggunakan metode deskriptif kualitatif. Data yang dianalisis adalah fenomena crosshijber yang berasal dari postingan media Onine seperti di Instagram, Youtube. Fenomena ini dianalisis dan dari beberapa penjelasan dalam kitab tafsir dengan menganalisis yang berkaitan dengan ayat hijab dalam al-Qur'an dan kontektualisasi sebuah perilaku yang dilakukan oleh komunitas crosshijaber. 


\section{HASIL DAN PEMBAHASAN}

\section{Pengertian dan Awal Kemunculan Crosshijaber di Media Sosial}

Secara bahasa crosshijaber berasal dari dua suku kata, yaitu cross dan bijaber. Cross yang mempunyai arti yaitu menyebrang, melintasi, merintangi. (http://kamusbahasainggris.com/, 2020). Sedangkan hijaber yaitu jilbab atau kerudung. Dalam bahasa Inggris jika sebuah kata yang ber-akhiran "er" berarti mempunyai arti menunjukkan subjek atau pelaku sebuah pekerjaan atau perbuatan tertentu. (Kimberly Adams \& A. A. Waskito). Dalam diskursus mengenai hijab mempunyai pengertian yaitu "penutup", karena merujuk kepada suatu alat untuk menutup, (Agus Efendi dan Alawiyah Abdurrahman, 1988). terdapat beberapa sinonim. Pertama, jilbab yaitu sebuah baju kurung yang sejenis dengan jubah. (Ahmad Warson Munawwir, 2002). Kedua, kerudung yaitu sebuah kain yang berfungsi sebagai penutup kepala perempuan. Ketiga, tiung (Bahasa Sunda) yang memiliki arti tidak jauh berbeda dengan pengertian sebelumnya. Menurut Ibnu Mas'ud menyatakan bahwasanya hijab adalah dengan menggunakan istilah al-rida (selendang), mantel atau jubah. Sedangkan masyarakat umum memaknai hijab dengan istilah al-izar yaitu sejenis pakaian yang longgar untuk menutup seluruh tubuh mulai dari ujung kepala hingga kaki. Dalam pandangan Ubaidah dan sahabat yang lain mengartikan hijab sebagai pakaian yang menjuntai keseluruh tubuh sehingga tidak ada anggota tubuh yang terlihat, kecuali telapak tangan dan mata, dan yang termasuk dalam pengertian ini adalah penutup muka (cadar). (Abu Said AlAnshori, 1994). Berdasarkan beberapa pengertian diatas, maka term hijab secara syari'at Islam yaitu pakaian perempuan yang dapat menutup seluruh tubuh kecuali muka dan telapak tangan. (Istadiyantha., 1984).

Pada dasarnya penggunaan hijab yang berarti "penutup" yaitu dengan alasan bahwa pada zaman dahulu jika masyarakat mempunyai harta kekayaan dan barang berharga, seperti intan, emas, dan lain-lain yang mempunyai daya jual tinggi, maka mereka menyembunyikannya dari para penguasa supaya tidak dirampas, bahkan dari anak-anaknya sendiri. Dengan alasan lain, zaman dahulu keamanan suatu daerah tidak terjamin, hal ini bukan hanya untuk harta dan kekayaan, namun terhadap perempuan dalam daerah tertentu. Dan jika ada seorang penguasa yang mengetahui kabar bahwa disuatu daerah tertentu terdapat perempuan yang cantik, maka penguasa tersebut berkuasa untuk menikahinya untuk dijadikan sebagai selir, diharuskan bagi lelaki untuk menyembunyikan atau dengan kata lain menutup perempuan-perempuan supaya tidak terlihat. (Agus Efendi dan Alawiyah Abdurrahman, 1988). 
Pengertian crosshijaber yaitu laki-laki yang gemar mengenakan busana perempuan yang lengkap dengan aksesoris seperti, hijab, gamis, dan cadar, (https://www.tagar.id/arti-danpenjelasan-crosshijaber-yang-bikin-heboh, 2019). Crosshijaber merupakan sebuah evolusi dari crossdresser yang sudah ada sejak zaman dahulu pada saat pentas seni, seperti drama yang menuntut seorang laki-laki mengenakan busana perempuan pada peran tertentu. Namun seiring dengan perkembangannya, berbagai model busana semakin bervarian, dan crosshijaber ini merupakan kolaborasi yang baru antara busana perempuan dan hijab. Sedangkan sejarah mengatakan bahwasanya hijab dan cadar adalah tradisi yang berasal dari Arab dan bukan berasal dari Indonesia. Dan pakaian tradisional pribumi masyarakat Indonesia pada zaman dahulu tidak mengenal hijab dan cadar, hijab dan cadar mulai masuk ke Indonesia dibawa oleh para transmigran yang berasal dari Arab dan sekitarnya untuk penyebaran agama Islam, namun bukan untuk menyebarkan tradisi ke-Arab-an, kemudian seiring menyebarnya Islam di Indonesia, perilaku dalam mengenakan hijab dan cadar mulai di tiru oleh masyarakat Indonesia.

Crosshijaber mulai viral di media sosial Indonesia seperti facebook, instagram yang bernama @infinity, dan mulai tayang di youtube pada tahun 2019. Pada akun media sosial instagram tersebut berisi postingan yang memperlihatkan beberapa foto seorang laki-laki yang mengenakan busana perempuan lengkap dengan aksesoris seperti, hijab, gamis, cadar, dan lain-lain yang berkaitan dengannya. Warga netizen spontan merespon dengan berbagai macam, seperti menghujat, mencaci, dan mengecam. Setelah beredar luas kabar negatif dari crosshijaber, kemudian postingan crosshijaber jejaknya sudah tidak bisa dilacak lagi karena postingannya sudah dihapus.

\section{Penyimpangan Crosshijaber}

Perempuan dan hijab adalah dua hal yang tidak bisa dipisahkan, karena hijab adalah sebuah identitas seorang perempuan yang agamis dan perhiasan baginya, (Cahirul Halim, 1998), hijab berfungsi sebagai pembeda antara perempuan muslim dengan non-muslim, dan yang paling inti adalah untuk membedakan laki-laki dengan perempuan. Selain itu, hijab adalah sebuah faktor mode pakaian sebagai simbolik budaya muslim. Namun keputusan untuk memakai hijab itu kembali kepada personnya masing-masing, (Li Chen, 2014), sebuah pilihan memakai hijab berarti menunjukkan komitmen dalam beragama yang ditunjukkan oleh seorang perempuan. (Syed Ali, 2005). Dalam penggunaan hijab itu sendiri menunjukkan sebuah klasifikasi strata sosial masyarakat yang bervariasi yang bisa dicirikan dalam bentuk hijab berdasarkan latar belakang daerah, usia, aliran agama, dan konteks sosial masyarakat. (Rema Hammam, 1990). Dilihat secara psikologi sosial, berhijab adalah cara untuk mengungkap bagaimana pakaian digunakan oleh manusia untuk membentuk perilaku mereka dengan orang lain setiap hari. Dalam masyarakat yang kompleks, ada 
sederetan orang lain dengan siapa kita harus menyesuaikan dalam berinteraksi, dan cara berpakaian, khususnya memakai hijab adalah mencerminkan posisi sosial sebagai ibu, guru, dokter, dan lain-lain. (Kim K.P. Johnson And Sharon Lennon).

Hijab di Indonesia mulai mengalami pergeseran makna, jika zaman dahulu hijab adalah sebagai penutup aurat, namun saat ini sudah menjadi fashion yang sedang menjangkit dan membius untuk menjadi sebuah gaya dalam berpakaian, perbedaan hijab zaman dahulu dengan sekarang sudah dikemas dengan sesuatu yang menarik, (Ade Nur Istiani, 2015), sehingga perempuan berbondong-bondong dan berlomba-lomba dalam berhijab. Bahkan bukan hanya perempuan dalam berhijab, baru-baru ini mulai bermunculan laki-laki yang gemar mengenakan hijab, yaitu crosshijaber. Crosshijaber adalah sebuah perilaku yang menyimpang dengan menggunakan hijab sebagai cara untuk menghalalkan dan menuruti hawa nafsunya.

Istilah yang digunakan untuk menggambarkan penyimpangan crosshijaber yaitu paraphilia. Paraphilia berasal dari bahasa Yunani, para yang berarti "lebih", dan philia yaitu "teman" atau "bersenang-senang". Sedangkan secara istilah, Paraphilia yaitu adalah sekelompok gangguan yang mencakup ketertarikan seksual terhadap objek yang tidak wajar atau aktivitas seksual yang tidak pada umumnya. (https://id.wikipedia.org/wiki/Parafilia, 2019). Berdasarkan pandangan ilmu kedokteran, perilaku crosshijaber adalah termasuk kedalam kelainan seksual dengan istilah Transvestitisme, yaitu kegemaran seorang lelaki yang mengenakan busana perempuan. Secara bahasa transvestisisme, berasal dari kata transvesti yaitu sebuah peran seorang wanita yang dilakukan atau dimainkan oleh laki-laki, atau sebaliknya dengan menggunakan pakaian yang aneh-aneh sehingga mengundang tawa penonton. (Tim Pustaka Agung Harapan). Dengan kebiasaan seperti itu, kemudian berdampak pada kelainan seksual, istilah kelainan seksual atau penyimpangan seksual (sexual devitation) dan bisa disebut dengan istilah abnormalitas seksual (sexual abnormality), ketidakwajaran seksual (sexual perversion), dan kejahatan seksual (sexual harrasment). penyimpangan seksual (deviasi sexual) bisa didefinisikan sebagai dorongan dan kepuasan yang tidak ditujukan kepada obyek tujuan sewajarnya. ( Didi Junaedi, 2016)

Dengan adanya crosshijaber yang beredar dimedia sosial, wajah hijab menjadi tercoreng, citranya menjadi buruk dimata masyarakat. Ada pergeseran nilai hijab yang dibangun oleh perempuan di Indonesia. Jilbab tidak lagi mengacu pada kerudung yang digunakan oleh wanita muslim, tetapi jilbab adalah didefinisikan untuk memakai jilbab dengan cara yang dimodifikasi. Pada awalnya masyarakat menganggap bahwa jilbab sebagai simbol kepatuhan perempuan terhadap ajaran agama. (Hiqma Nur Agustina, 2015). Namun dengan hadirnya crosshijaber menjadi sebuah ketakutan dalam masyarakat (fear in society) tersendiri, karena penyalahgunaan hijab dengan perbuatan yang negatif oleh beberapa oknum agar keinginannya terwujud walaupun sesaat, 
akibatnya masyarakat menjadi was-was dan berhati-hati jika dalam suatu tempat terdapat orang yang memakai hijab.

\section{Dampak Negatif Crosshijaber}

Berdasarkan paparan diatas, penulis memberikan beberapa dampak negatif yang ditimbulkan dari crosshijaber, seperti berikut. Pertama, pelecehan seksual, menurut pengakuan dari korban yang telah mengetahui crosshijaber, oknum crosshijaber telah melakukan beberapa tindakan yang tidak senonoh, seperti memeluk, memegang anggota vital perempuan, mencium, dan bahkan masuk ke dalam tempat-tempat khusus perempuan, seperti kamar tidur, kamar mandi tanpa disadari bahwa orang tersebut adalah lawan jenis. Kedua, kriminal yang meliputi pencurian barang elektronik, seperti handphone, laptop, dan perhiasan. Ketiga, penipuan, oknum crosshijaber menggunakan hijab dengan tujuan menipu tanpa diketahui dan tanpa disadari oleh korbannya terutama perempuan, karena hijab atau cadar secara otomatis menutup 95\% bagian wajah, dan sangat kecil kemungkinan diketahui identitas wajahnya. Beberapa dampak negatif tersebut berdasarkan keluhan dan opini masyarakat yang tersebar dari beberapa media sosial.

\section{Crosshijaber Apakah Sebuah Transgender?}

Timbul sebuah pertanyaan, apakah crosshijaber termasuk kedalam perilaku transgender?. Sebelumnya harus mengetahui terlebih dahulu mengenai pengertian transgender, batasan transgender, dan yang berkaitan dengan transgender. Pengertian transgender yaitu sebuah deskripsi yang digunakan untuk orang yang melakukan, merasa, dan melihat sebuah jenis kelamin yang berbeda pada kenyataan saat dilahirkan, sebuah gejala transgender itu diakibatkan karena adanya rasa ketidakpuasan, ketidakcocokan, ketidaknyamanan atau merasa terganggu terhadap jenis kelamin, kejiwaan dan bentuk fisik yang dimilikinya saat ini, kemudian merubahnya menuju lawan jenis kelaminnya, hal ini bisa dilihat dari cara berpakaian, ataupun menggunakan perlengkapan lawan jenis kelaminnya yang identik. (Wening Purbatin Palupi Soenjoto, 2016). Sedangkan batasan transgender yaitu seseorang yang merubah bentuk fisik secara total, yang meliputi alat kelamin, wajah, rambut, suara, bagian dada, cara berjalan, cara berpakaian, dan segala hal yang berkaitan dengan perempuan. Jika dilihat dari pengertian diatas, perilaku crosshijaber adalah bukan termasuk kedalam sebuah perilaku transgender, namun hanya sebatas kegemaran seorang laki-laki dalam mengenakan busana perempuan.

\section{Pandangan Terhadap Crosshijaber}

Dalam permasalahan crosshijaber, Gus Miftah (Pengasuh Pondok Pesantren Ora Aji, Kalasan, Sleman, Yogyakarta) berpendapat bahwasanya kembali kepada kesadaran individu, jika 
berdasarkan ayat tentang hijab dan menyesuaikan dengan budaya yang ada pada suatu daerah tertentu, Gus Miftah tidak memaksakan bahkan tidak langsung menjustice bahwasanya sesuatu tersebut adalah salah, namun Gus Miftah harus mengetahui dasar hukum dan hanya sekedar mendeskripsikan mengenai pakaian yang sesuai dengan syariat yang terdapat dalam al-Qur'an surat Al-Ahzab : 59. crosshijaber sudah terindikasi sebuah perbuatan negatif, maka itu sudah diluar dengan jalur hukum, bahkan crosshijaber adalah sebuah penistaan terhadap ayat al-Qur'an dan pelecehan seksual atau penyimpangan seksual dengan sebuah tindakan perilaku, dengan bukti adanya sebuah pelanggaran seperti bercampur dengan perempuan, masuk kedalam wilayah perempuan seperti toilet dengan tidak mengetahui apakah itu laki-laki atau perempuan. Letak pelecehan terhadap agama yaitu karena hijab adalah sebuah identitas agama yang tidak bisa diganggu gugat, berbeda jika hanya sebatas hobi memakai hijab saja, namun tidak menimbulkan perbuatan yang merugikan. Yang lebih parah apabila crosshijaber dapat merubah paradigma masyarakat bahwasanya crosshijaber adalah tidak salah.

Gus Miftah melanjutkan pendapatnya dengan mengatakan crosshijaber adalah sebuah pelanggaran etika berpakaian, karena dalam al-Qur'an surat Al-Ahzab : 59 menjelaskan bahwasanya hijab itu diperuntukkan perempuan bukan laki-laki, crosshijaber merupakan jelas-jelas penghinaan dan pelecehan terhadap perempuan karena ada tujuan lain. Adapun cara untuk menyadarkan para pelaku crosshijaber adalah melalui terapi secara psikologis, dan menasihati secara perlahan dan bertahap. (https://www.youtube.com/watch?v=ga1NmNvQ3_c, 2020).

Majelis Ulama Indonesia menganggap crosshijaber adalah suatu tindakan yang diharamkan dalam ajaran Islam dengan sebuah bentuk perilaku seperti, laki-laki yang menggunakan pakaian perempuan, tidak bisa mengidentifikasikan sebagai laki-laki, penyimpangan seksual berupa transvestisme. Motif crosshijaber dilihat secara dorongan seksual yaitu adanya kelainan hormon atau gangguan seksual lainnya, sedangkan tanpa adanya dorongan seksual yaitu timbulnya perilaku kriminal, teror dan motif lainnya. Dampaknya sebuah kekhawatiran mengenai batasan-batasan penggunaan ruang umum khusus wanita, seperti toilet atau tempat wudhu. (https://www.youtube.com/watch?v=DVcsQFy197A, 2020). Begitu juga menurut Masduki Baidlowi Ketua Bidang Informasi dan Komunikasi MUI, crosshijaber adalah sebuah perilaku yang dilarang oleh agama, baik laki-laki yang memakai pakaian perempuan, atau sebaliknya. (https://www.youtube.com/watch?v=6Iuy2et04Q8, 2020).

Tika Bisono seorang psikolog berpendapat bahwasasnya menangani Crosshijaber seharusnya melibatkan beberapa pihak, seperti polisi, psikolog, dan kriminolog. Tika Bisono menganggap Crosshijaber adalah sebuah kasus bukan fenomena, karena crosshijaber tidak terjadi disetiap provinsi, namun hanya terjadi dibeberapa daerah saja. crosshijaber dipandang dari kacamata 
psikolog ada sebuah latar belakang yang menimbulkan adanya crosshijaber yaitu lemahnya kepriabadian, tidak punya pekerjaan, tidak punya teman, sekolah gagal, bukan anak yang disayang oleh keluarga sehingga tidak adanya "science of belonging", tidak adanya kehangatan dalam keluarga. Biasanya latar belakang tersebut seorang anak mudah untuk melakukan sebuah perilaku yang berada diluar norma, sehingga gagal dalam berinteraksi dengan lingkungan, gagal dalam bersosial, gagal dalam memahami interaksi sosial, "lost in spesies", hilang arah tujuan hidup, dan solusinya dengan cara memberikan sebuah kesibukan pekerjaan. (https://www.youtube.com/watch?v=mxnJ9KR2gjE, 2020).

\section{Respon Masyarakat Terhadap Crosshijaber}

Keberadaan crosshijaber di media sosial menuai beberapa tanggapan dari penjuru masyarakat dunia maya, mulai dari kecaman, hujatan, dan bahkan amarah, hal ini bisa dilihat dari komen-komen netizen pada media sosial dengan bahasa yang beragam, bahkan menggunakan bahasa kasar, dengan alasan crosshijaber berpotensi menimbulkan beberapa dampak yang negatif yang merugikan masyarakat. Respon tersebut bukan hanya sekedar ucapan semata, namun ada beberapa tindakan yang nyata, dengan cara meringkus para oknum crosshijaber oleh pihak berwajib setelah menerima laporan yang meresahkan dari masyarakat. Tindak lanjut ini mulai dilakukan karena dampak negatif yang diketahui berdasarkan beberapa postingan yang viral di media sosial. Pada awalnya masyarakat belum menyadari akan kehadiran crosshijaber adalah seorang laki-laki yang mengenakan hijab dan cadar, karena tidak bisa teridentifikasikan, namun dengan kecerobohan dari crosshijaber akhirnya mulai terkuak tindakan penyimpangan crosshijaber.

Atas laporan dari masyarakat kepada pihak yang berwajib karena dampak yang ditimbulkan oleh crosshijaber, kemudian pihak berwajib melakukan tindak lanjut. Seperti di kota Bandung, anggota Satpol PP perempuan atau yang lebih dikenal dengan nama "mojang-mojang Satpol PP" mulai bergerak atas instruksi dari komandan untuk menggelar patroli dan menyebar menuju beberapa masjid di kota Bandung. Taspen Efendi selaku Kabid Satpol PP kota Bandung menyatakan bahwa dengan sengaja menginstruksikan anggotanya yang berjenis kelamin perempuan dengan alasan karena supaya lebih mudah dan efisien ketika menyisir dengan cara yaitu berbaur dengan para jamaah perempuan dan beberapa wilayah yang itu khusus diperuntukkan bagi perempuan saja, seperti toilet, tempat wudhu, shaf shalat jamaah perempuan. Tindakan yang dilakukan oleh anggota Satpol PP ini bertujuan untuk meminimalisir berkembangnya wabah crosshijaber yang meresahkan masyarakat dengan harapan yang lebih yaitu menghilangkan tindakan crosshijaber. Berdasarkan laporan tersebutlah, Satpol PP mulai 
meningkatkan pengawasan yang lebih intensif terhadap masjid terutama wilayah perempuan. (https://www.youtube.com/watch?v=IOxQ30PYS9E, 2020).

Sedangkan di kota Surabaya respon masyarakat terhadap crosshijaber yaitu merasa risih dan keberatan, kemudian melaporkan kepada pihak berwajib seperti Satpol PP dan Linmas untuk mengerahkan anggota Askar Al-Muhajirin yang beranggotakan perempuan yang sudah dilengkapi dengan bekal bela diri untuk menjaga sejumlah masjid yang berada di kota Surabaya dengan bertugas selama 24 jam setiap hari. Selain itu, pemerintah kota Surabaya mengajak dan menghimbau kepada sejumlah takmir masjid di Surabaya untuk lebih berhati-hari dan waspada terhadap para jamaah lain, dan jika masyarakat mulai merasakan gangguan yang ditimbulkan oleh crosshijaber, maka dianjurkan untuk segera melaporkan kepada pihak berwajib dengan menghubungi nomor yang telah disediakan yaitu 112. Semua antisipasi ini dilakukan semata untuk melayani masyarakat demi kenyamanan dalam melakukan ibadah bagi semua pihak jamaah. (https://www.youtube.com/watch?v=GYBSRN7Padk\&t=29s, 2020).

\section{SIMPULAN}

Kemunculan crosshijaber di media sosial yang terjadi di beberapa daerah di Indonesia menuai beberapa macam respon dari masyarakat, crosshijaber adalah sebuah fenomena yang baru dalam dunia busana muslimah, karena crosshijaber adalah sebuah perilaku dari seorang laki-laki yang gemar menggunakan pakaian perempuan lengkap dengan beberapa asesoris, seperti hijab, gamis, cadar, dan lain-lain. Namun, sebelum adanya crosshijaber sudah dikenal dengan istilah crossdresser, yaitu seorang laki-laki yang menggunakan pakaian perempuan dalam pentas seni, yang menuntut untuk menggunakan pakaian perempuan, sehingga mengundang gelak tawa para penonton. Menurut pandangan ahli psikolog, munculnya crosshijaber karena adanya faktor yang menyebabkan seorang laki-laki gemar menggunakan pakaian perempuan bisa dilihat dari faktor internal dan eksternal. Faktor internal yaitu adanya pengaruh dari keluarga yang mendidik ketika usia dini, seperti orangtua yang mengajarkan untuk mengenakan busana perempuan, padahal anaknya berjenis kelamin laki-laki, terjadinya perpecahan dalam keluarga, sehingga seorang anak kehilangan jati diri terhadap konsistensi jenis kelaminnya. Sedangkan faktor eksternalnya yaitu media sosial yang kemudian ditiru dalam kehidupannya.

Dibalik munculnya crosshijaber yang dilakukan oleh seseorang ada tujuan negatif yang berdampak pada hilangnya sebuah wajah dan pandangan dari perempuan yang selalu mengenakan hijab. Hijab digunakan untuk melakukan beberapa tindakan negatif yang merugikan pihak-pihak tertentu, terutama perempuan, seperti terjadinya pelecehan seksual, tindakan kriminal seperti perampokan barang-barang berharga berupa alat elektronik. Dengan menggunakan hijab, 
kemungkinan untuk diketahui secara langsung itu sangat minim sekali, karena seluruh tubuh tertutupi oleh gamis, hijab dan cadar. Hal ini menjadi peluang besar bagi orang yang mempunyai niat negatif hanya untuk kenikmatan sesaat.

Perilaku crosshijaber adalah jelas-jelas tindakan yang menyimpang dalam agama berdasarkan al-Qur'an surat al-Ahzab : 59 dan sabda Nabi Muhammad. Kedua nash ini berisi ketentuan hijab dan sebuah larangan bagi pelaku yang menyimpang dalam berbusana. Respon dari pemuka agama berdasarkan pada interpretasi nash tersebut sangat sesuai melalui pendapatnya. Dampak dari perilaku menyimpang tersebut akhirnya pelaku diamankan oleh pihak berwenang karena dapat merugikan orang lain.

\section{SIMPULAN}

Dibalik munculnya crosshijaber yang dilakukan oleh seseorang ada tujuan negatif yang berdampak pada hilangnya sebuah wajah dan pandangan dari perempuan yang selalu mengenakan hijab. Hijab digunakan untuk melakukan beberapa tindakan negatif yang merugikan pihak-pihak tertentu, terutama perempuan, seperti terjadinya pelecehan seksual, tindakan kriminal seperti perampokan barang-barang berharga berupa alat elektronik. Dengan menggunakan hijab, kemungkinan untuk diketahui secara langsung itu sangat minim sekali, karena seluruh tubuh tertutupi oleh gamis, hijab dan cadar. Hal ini menjadi peluang besar bagi orang yang mempunyai niat negatif hanya untuk kenikmatan sesaat.

\section{DAFTAR PUSTAKA}

Adams, kimberly, \& Waskito, A. A. (t.t.). Dalam Kamus Inggris - Indonesia, Indonesia - Inggris. KAWAHmedia.

Agung harapan, tim pustaka. (t.t.). Kamus ilmiah populer "pegangan untuk pelajar dan umum."

Al-maududi, abu a’la. (t.t.). Al-hijab. dar al-fikr.

Ali, S. (2005). Why here, why now? Young Muslim women wearing hijab. MUSLIM WORLDHARTFORD THEN OXFORD-, 95(4), 515.

Al-Qabira Mushaf Terjemah Tajwid Warna. (2017). UD. NUR ILMU.

Antisipasi crosshijaber, Mojang Satpol PP patroli di masjid masjid. (t.t.). Diambil 16 April 2020, dari https://www.youtube.com/watch?v=IOxQ30PYS9E

Aris. (t.t.). Kamus Bahasa Inggris Online—Kamus Inggris Indonesia. KamusBahasaInggris.com. Diambil 21 Maret 2020, dari http://kamusbahasainggris.com/

As-Suyuthi, A.-M. (t.t.). Tafsir Jalalain. Darul Ilmi. 
Budiati, A. C. (2011). Jilbab: Gaya Hidup Baru Kaum Hawa. Jurnal Sosiologi Islam, 1(1).

Chen, L., Akat, H. D., Xin, C., \& Song, S. W. (2014). Retbinking hijab: Multiple themes in muslim women's perception of the bijab fashion. 214.

Fakta dan Penjelasan Crosshijaber. (t.t.). Diambil 16 April 2020, dari https://www.youtube.com/watch?v=DVcsQFyl97A

Halim, C. (1998). Wanita Mengapa Merosot Akblaknya. Gema Insani Press.

Hammami, R. (1990). Women, the Hijab and the Intifada. Middle East Report, 20(3 \& 4), 24-28.

Hartini, D. (2019). PAKAIAN SEBAGAI GEJALA MODERNITAS (Kajian Surat Al-Ahzab Ayat 59 dan Surat Al-Nur Ayat 31). At-Tibyan: Jurnal Ilmu Alqur'an dan Tafsir, 4(1), 26-44.

Heboh Fenomena Crosshijaber, Pria tapi Pakai Cadar, Gamis dan Masuk Toilet Perempuan-Tribun Jabar. (t.t.). Diambil 16 April 2020, dari https://jabar.tribunnews.com/2019/10/14/hebohfenomena-crosshijaber-pria-tapi-pakai-cadar-gamis-dan-masuk-toilet-perempuan

HR. Bukhari. (t.t.).

Istadiyantha, I. (1984). Hikmah Jilbab Dalam Pembinaan Akblak. CV. Ramadhani.

Istiani, A. N. (2015). Konstruksi Makna Hijab Fashion Bagi Moslem Fashion Blogger. Jurnal Kajian Komunikasi, 3(1), 48-55.

Junaedi, D. (2016). Penyimpangan Seksual Yang Dilarang Al Quran. Elex Media Komputindo.

Kebaya. (2019). Dalam Wikipedia bahasa Indonesia, ensiklopedia bebas. https:/ /id.wikipedia.org/w/index.php?title=Kebaya\&oldid=14919525

MUI Soroti Kelompok "Crosshijaber" di Medsos. (t.t.). Diambil 16 April 2020, dari https://www.youtube.com/watch?v=6Iuy2et04Q8

Munawwir, A. W. (2002). Al-Munawnir Kamus Arab - Indonesia. pustaka prosresif.

Muthahhari, M. (1988). On The Islamic Hijab. Terj. Agus Efendi Dan Alawiyah Abdurrahman, Hijab Gaya Hidup Wanita Islam. mizan.

Najitama, F. (2014). Jilbab Dalam Konstruksi Pembacaan Kontemporer Muhammad Syahrûr. Musãwa Jurnal Studi Gender dan Islam, 13(1), 9-18.

Parafilia. (2019). Dalam Wikipedia bahasa Indonesia, ensiklopedia bebas. https://id.wikipedia.org/w/index.php?title=Parafilia\&oldid $=15033232$

sharron J. Lennon, Johnson, K. P., \& Rudd, N. A. (2017). Social psychology of dress. Fairchild Bloomsbury.

Shihab, M. Q. (2012). Jilbab, Pakaian Wanita Muslimab: Pandangan Ulama Masa Lalu dan Cendikiawan Kontemporer (Vol. 1). Lentera Hati Group.

Sidiq, U. (2010). Diskursus Makna Jilbab dalam Surat al-Ahzab ayat 59: Menurut Ibnu Kathir dan M. Quraish Shihab. Kodifikasia, 6(1), 1-26. 
Soenjoto, W. P. P. (2016). Aktualisasi Transgender di Kabupaten Jombang. Journal An-Nafs: Kajian Penelitian Psikologi, 1(2), 203-242.

Surabaya Terapkan Penjagaan Antisipasi Cross Hijaber. (t.t.). Diambil 16 April 2020, dari https: / / www.youtube.com/watch? $\mathrm{v}=$ GYBSRN7Padk\&t $=29 \mathrm{~s} \% 2 \mathrm{C}$

Taimiyah, I. (1994). Majmu' Risalab Fi Hijab Was Sufur. Terj. Abu Said Al-Anshori, Jlbab Dan Cadar Dalam Al-Qur'an Dan Sunnah. pedoman ilmu jaya.

Toyyib, M. (2018). KAJIAN TAFSIR AL-QUR'AN SURAH AL-AHZAB AYAT 59. ALIBR AH, 3(1), 66-93.

Yulikhah, S. (2017). Jilbab Antara Kesalehan dan Fenomena Sosial. Jurnal Ilmu Dakwah, 36(1), 96117. 